\title{
The Impact of Socialist Imprinting and Search for Knowledge on Resource Change: An Empirical Study of Firms in Lithuania
}

\author{
By: Aldas Kriauciunas and Prashant Kale
}

William Davidson Working Paper Number 446

March 2002 


\title{
The Impact of Socialist Imprinting and Search for Knowledge on Resource Change: An Empirical Study of Firms in Lithuania
}

\author{
Aldas Kriauciunas \\ Ph.D student - Corporate Strategy and International Business \\ University of Michigan Business School \\ 701 Tappan Street \\ Ann Arbor, MI 48109-1234 \\ Phone: (734) 647-0255 \\ Email: aldas@umich.edu \\ Prashant Kale \\ Asst. Professor of Corporate Strategy and International Business \\ University of Michigan Business School \\ 701 Tappan Street, D4209 \\ Ann Arbor, MI 48109-1234 \\ Phone: (734)-764-2305 \\ Email: kale@umich.edu
}

Note: The authors would like to thank the William Davidson Institute, the University of Michigan Business School Doctoral Grants Committee, Verslo Zinios business daily, Central Securities Depository or Lithuania, and Kaunas Technological University for providing funding and support for this study. 


\title{
The Impact of Socialist Imprinting and Search for Knowledge on Resource Change: An Empirical Study of Firms in Transitional Economies
}

\begin{abstract}
In this paper we examine how firms change their resources in response to exogenous shocks in their business environment. Building on core ideas from the literatures on organizational imprinting and firm resources, we suggest that founding conditions differentially imprint firm resources. These initial imprinting differentials in turn influence the search for knowledge required to adapt or change firm resources in the face of external change in their business environment. We also suggest that the level of imprinting and the location of search independently and jointly influence the success with which firms are able to change their resources.
\end{abstract}

We use survey-based data from a set of firms in Central Europe that experienced an exogenous shock in 1989-1991 to test our arguments. We develop a measure of pre-shock imprinting (called socialist imprinting) on resources and use it to predict where firms will search for knowledge to undertake change in the post-shock period and how successful that change will be. We find that the level of socialist imprinting influences the search location for knowledge to change key resources and activities following the shock. In terms of the success of change undertaken, we see that distant search for knowledge is positively linked to it. We also observe that the level of imprinting and search location jointly impact the success of change; for resources with higher socialist imprinting, distant search was more effective than local search.

This research makes three important contributions in the context of existing research on organizational imprinting and firm level change. One, it focuses on firm-level resources to examine the impact of imprinting. Two, we examine how differences in resource level imprinting influence the search for new knowledge required to transform these resources. Three, we demonstrate that the interaction between the level of imprinting and the nature of search has important influences on firm performance. Our findings also provide insights to practitioners and policy makers who deal with firms in transitional economies. Practitioners can better understand how to undertake firm level change more effectively in the context of sudden exogenous shock. For policy makers, both of domestic and international institutions, understanding the change process can help formulate assistance programs more effectively.

Keywords: organizational imprinting, transitional economies, change 


\section{INTRODUCTION}

'Why do firms approach change the way they do?' This question is at the core of many organizational and strategy theories (Cyert and March, 1963; Nelson and Winter, 1982; Wernerfelt, 1984; Hannan and Freeman, 1977 and 1984). Different perspectives, ranging from population ecology to the resource-based view of the firm, agree that firms can and do change, but they vary in terms of their view on how change is approached. The literature on firm-level change has examined a large number of issues related to why firms undertake change differently, including market failure for resources (Capron, Dussauge, and Mitchell, 1998), network location (Stuart and Podolny, 1996), firm performance and firm diversity (Barker and Duhaime, 1997). In this paper we extend that research by considering the differential impact of organizational imprinting (Stinchcombe, 1965) on firms and how it influences the search processes that firms undertake to acquire knowledge necessary to change in the face of huge exogenous shocks in the external business environment. Specifically, our core research question is how does the founding economic environment impact firm resources and the search for knowledge to undertake change in those resources at subsequent points in time? We also investigate the independent and joint impact of organizational imprinting and the search process on the success of the change undertaken.

We study this question within the context of transitional economies. Specifically, we study firms founded in the socialist economic environment prevalent in Central Europe through 1990 and examine their search location for knowledge to transform some of their core activities or resources following the exogenous shock they experienced in 1989-1991. This is an opportune setting since the shock pressured almost all firms in the region to adjust their resources. We develop a measure of the pre-shock imprinting on resources (called socialist imprinting) and use it to predict where firms will search for knowledge to undertake change in the post-shock period and how successful that change will be. The results indicate firms that used distant search to acquire knowledge had higher levels of success in changing their resources. Additionally, for resources with higher socialist imprinting, distant search was more effective than local search; in contrast for resources with low socialist imprinting, local search was more effective than 
distant search for undertaking resource change. These results indicate that given large environmental change, firms may be more successful by not only building on past resources, but also creating new resources that reflect the changed environment.

This research builds upon and contributes to the organizational imprinting literature (Stinchcombe, 1965) and research on transitional economies. Current research on organizational imprinting and its impact on firms shares certain characteristics. One, for the most part it considers only the entire organization as the primary unit of analysis (Schein, 1983; Romanelli, 1989). Only recently, have scholars begun to focus on the effects of imprinting on sub-parts of the firm such as Bamford, Dean and McDougall (1999), Boeker (1989), and Zyglidopolous (1999). Two, most prior research assumes that imprinting uniformly impacts different sub-parts or resources within firms. Three, prior research shows that when the environment changes from the type within which the firm was founded, performance decreases (Romanelli, 1989; Bamford, Dean, and McDougall, 1999). We address some of the gaps in the above research as follows: One, instead of the firm as the unit of analysis, we focus on firm-level resources to examine the impact of imprinting. Two, we suggest that imprinting differentially impacts various resources within firms. Three, we then examine how these differences in imprinting will influence the search for new knowledge required to transform these resources in the face of sudden change. Four, we also demonstrate that interaction between the level of imprinting and the nature of search has important influences on firm performance.

The developments in the transitional economies of Central and Eastern Europe over the past 10-15 years provide an excellent context to study the above issues, given the large exogenous shock that occurred in the late 1980s and early 1990s and the relatively short period within which the shock occurred. We can potentially shed some valuable insights into the management of firms in these economies. Firms founded before 1990 were imprinted by the socialist economic system ${ }^{1}$. In 1990, they experienced a large exogenous shock in terms of how their economic environments were organized and needed to change or adapt to this significantly different environment. By examining their 
search process for knowledge to undertake change at the resource level, we can examine imprinting at the resource level and determine the difference in organizational imprinting strength across different resources. This approach not only expands our understanding of organizational imprinting and the resource-based view of the firm but also increases our knowledge of firms in transitional economies by addressing a need stated by Hoskisson, Eden, Lau, and Wright (2000): "There is a need to develop theoretical and empirical understanding of the factors promoting and restricting the emergence of new market economies.... The challenge ahead for strategy researchers is to identify how enterprises in differing emerging economies can overcome external and internal impediments to the design and implementation of successful market-based strategies". [Pg. 264]

Our findings may also benefit practitioners and policy makers who deal with firms in transitional economies. They can better understand how to undertake firm level change more effectively in the context of their sudden exogenous shock. For policy makers, both of domestic and international institutions, understanding the change process can help them form assistance programs more effectively. The results indicate that not all resources of the firm were equally imprinted by the socialist system. Perhaps more importantly, firms coming out of the socialist system appear better able to undertake change than previously believed.

The remainder of this paper is organized as follows. In section 2, we review relevant work on organizational imprinting, the resource-based view of the firm, and search. We use their theoretical ideas to develop four hypotheses with transitional economies as the context. In section 3, we provide information on the data, the sample, and operationalization of the variables. The results and analysis are presented in section 4. In section 5 we discuss the results and in section 6 , we present the discussion of our results and conclusion.

\footnotetext{
${ }^{1}$ In 1990, the Berlin Wall fell, the level of private ownership was starting to increase in Central Europe, and the Baltic States broke away from the Soviet Union. For that reason, 1990 is the cut-off year used for the exogenous shock.
} 


\section{THEORY AND HYPOTHESES}

This research builds on several core literatures in strategy and organizational theory, namely research on organizational imprinting (Stinchcombe, 1965), the resourcebased view of the firm (Penrose, 1959; Barney, 1991) and firm search (Cyert \& March, 1963). We shall first present some of the core ideas from these research streams that create the foundation and context of our theory. We then present specific hypotheses within the context of transitional economies.

\section{Organizational Imprinting}

Imprinting refers to the impact that founding conditions, such as the environment, have on an entity and the persistence of these founding conditions. Stinchcombe (1965) provides three reasons for the persistence of organizational imprinting. One, firm characteristics, as represented when founded, continue to be the best way to organize and do business. Two, the firms are insulated from competitive pressures as a result of outside support or strong internal traditions. Three, the firm may not have endured sufficient competitive forces, so there has been no pressure to change how it does things.

Past research has examined imprinting at the country-level (Kogut, 1993) and population-level (Tucker, Singh, and Meinhard, 1990). However, the most common unit of analysis for imprinting is the firm or organization ${ }^{2}$. In general, three different facets of a firm's or organization's resources may be imprinted: its overall structure and strategy; the technology, patterns of activity, and routines that govern the organization's day-today activities; and organizational culture (Sastry and Coen, 2000). The firm-level organizational imprinting research primarily considers imprinting based on founder characteristics and imprinting based on environmental characteristics. The concept of imprinting means that decisions made and environmental conditions existing at the formation (founding) stage of an organization imprint the firm and have a continued impact on the firm's actions and performance.

\footnotetext{
${ }^{2}$ In this paper, we interchangeably use the terms 'organization' and 'firm'. Past research looks at both firms and organizations, but this line of research only considered firms.
} 
Organizational imprinting related to the founder has focused on the initial culture or knowledge that founders bring (Pennings, 1982; Schein, 1983; Mintzberg and Waters, 1982; Eisenhardt and Schoonhoven, 1990). It shows that the imprint effect continues to exist at later points in time. Organizational imprinting related to the environment has received even greater attention (Bamford, Dean, and McDougall, 1999; Eisenhardt and Schoonhoven, 1990; Romanelli, 1989; Pennings, 1982; Boeker, 1989). The results indicate that the founding environment impacts the probability of firm founding, initial and later strategies, and future levels of growth. Environmental conditions include technological, economic, legal, competitive, and social aspects Zyglidopoulos (1999). Environmental imprinting requires two conditions: (1) a mapping of the environmental condition(s) onto the firm; and (2) some inertia in the imprinted characteristics (Carroll and Hannan, 2000). In this study, we focus on the initial economic environment.

Besides looking at the source of imprinting, it is equally important to consider the target of the imprinting within the firm (Sastry and Coen, 2000). Previous studies that look beyond the surface of the firm have examined imprinting on strategy (Eisenhardt and Schoonhoven, 1990; Romanelli, 1989), distribution of power among subunits (Boeker, 1989) and technological trajectory (Zyglidopoulos, 1999). Imprinting on resources, the focus of the next section, has not been examined in previous research.

\section{Resource Based View of the Firm}

The firm can be considered a collection of productive resources, both tangible and intangible (Penrose, 1959; Rubin, 1973; Wernerfelt, 1984 and 1995; Amit and Schoemaker, 1993). Resources include all assets, capabilities, processes, and attributes controlled by a firm to implement strategies for better performance (Barney, 1991). The initial resources that a firm has are what it obtains from either its founder or from its environment (Stinchcombe, 1965). Together, the organizational imprinting perspective and resource-based view of the firm indicate that founding economic conditions can impact a firm's resources. We believe that founding economic conditions will have varying degrees of imprint on the initial resources of the firm since the resources themselves can vary significantly. They can be physical capital resources, human capital 
resources (Penrose, 1959; Barney, 1991) or organizational capital resources (Barney, 1991). They are fungible, indicating they can be used across products and services (Penrose, 1959; Wernerfelt, 1984; Anand and Singh, 1997). Some are more subject to market failure than others (Capron, Dussauge, and Mitchell, 1998) and vary based on their rareness and substitutability. Given the dimensions along which resources can vary, this suggests that the level of environmental imprinting will also vary.

The differences of imprinting across resources persist over time because a firm's previous investments and current set of routines constrain future behavior, especially as learning tends to be local (Teece, Pisano, and Shuen, 1997). However, change can occur within the current set of resources by adding new knowledge to that current set of resources (Nelson and Winter, 1982; Grant, 1996). By obtaining knowledge, a firm undertakes learning and as a result has the capacity to change (Grant, 1996). The ability to incorporate new knowledge into current resources depends on the absorptive capacity of the firm (Cohen and Levinthal, 1990). For new knowledge to be added to the existing resources there needs to be additivity between the new knowledge and the existing resources (Grant, 1996). Firms will try to use new knowledge that best fits with the existing resources of the firm. The idea of search (Cyert and March, 1963) can explain where the firm searches for this new knowledge to combine with current resources to undertake change.

\section{Search Location}

Cyert and March (1963) proposed that firms undertake search to identify a solution for a specific problem, starting in the vicinity of the problem. Firms will undertake a search in the neighborhood of the problem solution (called local search) and if that fails, it will use more complex (called distant) searches (Cyert and March, 1963). Such a structured approach is often used to obtain specific information or solutions (Raymond, Julien, and Ramangapahy, 2001). Nelson and Winter (1982) also propose that local search will be the initial response to problem solving. They indicate that organizations find it hard to change routines once they are in place. Thus, firms are better 
at doing more of what they have done in the past than changing what they do (Nelson and Winter, 1982).

Together the above three streams of literature provide a foundation for the core theoretical argument and hypotheses that we propose. Cyert and March's (1963) development of search is based on the search being undertaken for a reason and being directed towards a goal. Based on the explanation presented earlier, the goal of search is to identify new knowledge to incorporate with current resources to undertake change. Based on the knowledge-based view, we know that that new knowledge must ideally be able to be combined with existing resources. Through organizational imprinting, we know that current resources are a reflection of initial resources. Therefore, it follows that the level of imprinting on resources by the founding economic environment will impact the type of new knowledge that is combined with current resources to undertake change. Further, since different types of knowledge can be found in different search locations, it follows that the level of imprinting on resources by the founding economic environment will impact the location of search for new knowledge to undertake change at later points in time.

\section{Imprinting and the Location of Knowledge Search}

In the context of transitional economies, the socialist economic environment at the time of the firms' founding will imprint on the firms' resources ${ }^{3}$. We refer to this as socialist imprinting. As we previously developed, founding economic conditions will have varying degrees of imprint on the initial resources of the firm. This variance of imprint strength will continue through subsequent points in time, even if a large shock occurs. This means that in the immediate time period following the shock, resources that had strong socialist imprinting will continue to have strong socialist imprinting and likewise for resources with weak socialist imprinting. Around 1990, the socialist countries of Central and Eastern Europe, including Lithuania, experienced a significant exogenous shock. Their economic systems began to move from being socialist-based,

\footnotetext{
${ }^{3}$ For socialist countries, the Communist Party both created the economic environment and was the founder of the firms. For simplicity, we only focus on the impact of the economic environment.
} 
centrally planned to free-market based. This required the previously socialist firms to change all their resources within a short period of time to adjust to the new economic environment. Externally, firms faced loss of markets, hyperinflation, currency changes, loss of suppliers, and lack of proper legal systems (Chikan and Demeter, 1995). Internally, resources had to be changed to achieve new production techniques, better quality, improved management structures, new products (Chikan and Demeter, 1995), accounting and personnel management systems (Ericson, 1998). As part of the process to change their resources, the previously socialist firms began to search for knowledge to transform their current resources.

Since the level of socialist imprinting varies across resources, the search location for knowledge is also expected to vary between the resources. The basis for this variance is that for change to occur, resources need to be combined with like knowledge (Grant, 1996). For resources that have strong socialist imprinting, the knowledge needs to be of a similar (i.e. high) level of socialist imprinting. Likewise, for resources that have weak socialist imprinting, the knowledge needs to be of a similar level of socialist imprinting. Since the transitional economies had just come out of the socialist system, their knowledge base would be primarily socialist based. So, to change resources that have strong socialist imprinting, firms will look for knowledge within the country to undertake change. We call this local search. However, for resources that have weak socialist imprinting, firms will look for knowledge abroad to undertake change. This is because the required weakly socialist imprinted knowledge will only be found abroad, such as in historically free market countries. We call this distant search. So, we propose a relationship between the level of socialist imprinting and the search location.

H1: The greater the socialist imprinting of a particular resource, the more likely the firm will undertake local search for knowledge to undertake change.

Of course, some scholars may argue the opposite. Resources with weak socialist imprinting may only require minor changes to be useful in the new economic setting. As a result, local search may be sufficient to find the knowledge needed to undertake change. Also, resources with strong socialist imprinting may be insufficiently changed if only 
local search is used for knowledge to undertake change. With strongly socialist imprinted resources, perhaps only knowledge identified through distant search will result in a large enough change for the resources to be useful in the new economic setting.

\section{The Success of Change}

We now consider how the level of imprinting and the location of knowledge search to change firm resources influence the eventual success of that change. We also examine the joint impact of these two factors on the success of change.

In undertaking change, firms will build on the current set of resources (Teece, Pisano, and Shuen, 1997; Nelson and Winter, 1982). Thus, the current set of resources constrains future behavior as learning tends to be local. However, there are situations for which local search may not be the best option. Given large levels of pressure to change, the firm may have to move to radically new options (Cyert and March, 1963; Staw, Sandelands, and Dutton, 1981). For example, Capron and Mitchell (1999) presents four modes of change and indicate that an external mode of change, similar to distant search, will be undertaken to obtain sufficiently different capabilities than what a firm presently has. As a result, when large shifts occur in the environment a firm may need to undertake distant search for its new knowledge needs.

The economic and political shock in Central and Eastern Europe resulted in a very large environmental shift. Firms needed to work in a completely different economic environment than what they had been accustomed to. Radical changes were needed to all resources that a firm had, since the resources had to be adapted to a new economic system. Local search for knowledge to change the current resources would be inadequate, since the combination will produce a changed resource that is only slightly different from what the firm had. These slightly changed resources will be insufficient to meet the needs of the transitional economy. Only distant search would provide the knowledge needed to be combined with current resources to meet the needs of the transitional economy. Obtaining the more appropriate knowledge through distant search 
to undertake resource change should increase the likelihood of success of the change of that particular resource.

H2: In transitional economies, distant search for knowledge has a greater positive impact on the success of change than local search.

Research on change in firms indicates that most firms use an incremental process for undertaking change (Banbury and Mitchell, 1995; Barnett and Carroll, 1995, Nagarajan and Mitchell, 1998). This is because larger changes are very difficult to undertake. Generally, the greater the magnitude of change within the resource base, the more difficult the change process (Leonard-Barton 1992; Szulanski 1996). Large changes in the resource base have been linked to decreased firm performance and to firm failure, both because large change is difficult (Barnett and Carroll, 1995; Dial and Murphy, 1995) and because the firm's resources before the change are in misalignment with the environment. This indicates that the greater the gap between a firm's resources and its environment, the more difficult the process to realign the resources with the new environment.

In the transitional economy context, the economic environment very suddenly became misaligned with the resources within the firms. The resources were based on a socialist economy, but suddenly, the economy was based on free-market principles. However, not all the resources of the firms were equally misaligned with the new environment. The resources with weak socialist imprinting were more closely aligned with the new environment than the resources with strong socialist imprinting. Thus, the resources with strong socialist imprinting will be harder to change and align with the new environment. Since the level of difficulty associated with a change has a negative impact on the expected success of the change (Henderson and Clark, 1990), we can argue that the greater the level of socialist imprinting on current resources, the more difficult will it be to change those resources. Therefore,.

H3: In transitional economies, the greater the level of socialist imprinting of a particular resource, the lower the success of the change. 
Hypotheses 2 and 3 state that success of resource change is independently influenced by the search location and the level of economic imprinting. However, it would be equally interesting to examine their joint impact on the success of change. Is the impact of imprinting on change influenced by the location of search undertaken to acquire knowledge to change that resource. Similarly, an interesting question is what occurs if search location for knowledge to undertake change does not reflect the imprinting impact of founding economic environment as predicted? The previous argument about the relationship between imprinting levels and the location of search, emphasized that like knowledge needs to be combined with like resources - therefore firms may need to search locally to acquire that like or similar knowledge.

However, is it valid to assume that this will be true in all cases? One can imagine situations, such as closing old plants, when the misalignment between the current resources and the environment is sufficiently large, that the current resources are completely removed and completely new resources and new knowledge are brought in. Past research indicates that for sufficiently large resource-environment misalignments, the old resources will not be used (Henderson and Clark, 1990). In transitional economies, this would indicate that for strongly socialist imprinted resources, firms will undertake distant search for knowledge to build up a new foundation for the resource. Otherwise, the resource will not be sufficiently altered to allow the firm to survive in the new economic environment. In essence, the relationship between the level of imprinting and success of change will depend upon the location of search such that for high levels of imprinting, distant search is useful to undertake successful change.

H4: In transitional economies, the level of socialist imprinting and the location of search have a joint impact on the success of the resource change. For high levels of socialist imprinting, distant search will have a greater impact on the success of change than local search.

To summarize the four main hypotheses, we first suggest that the search location will depend on the level of socialist imprinting of the resource undergoing change. Further, the success of the change will depend on the search location and strength of 
socialist imprinting. By combining the two direct effects on success of the change, we predict that the level of socialist imprinting will moderate the influence of search location on performance. By changing the assumption of combining like knowledge with like resources, contrasting moderating effects are predicted.

\section{METHODS}

Sample: To test our hypotheses we collected data from a target sample of companies in Lithuania. The sample comprises companies that were the largest nonfinancial firms in Lithuania operating in 1998-1999 and that had been founded before the exogenous shock of 1990. These were firms that appeared in the 1998 list of the 300 largest firms in Lithuania or the 1999 list of the 400 largest firms in Lithuania. In total, 195 pre-1990 founded firms appeared on at least one of the two lists. Lithuania was chosen for this study given its similarity to many countries in the region. As a part of the Soviet Union from 1940 to 1990, it experienced strong socialist and communist pressures and is representative of other former Soviet republics. However, unlike most the former Soviet Union republics, Lithuania was an independent country through 1795, again independent from 1918 to $1940^{4}$. This history of independence and economic development makes Lithuania reflective of other Central and East European countries.

We collected survey data from the 195 firms in this sample. Of the 195 firms, we received completed responses from 67 firms. This response rate of $34.4 \%$ compares favorably with the average response rates observed for survey-based studies in transitional economies (Hoskisson et al, 2000). To check for non-response bias, we compared the size (revenue and employees) and industry of the respondent and nonrespondent firms and the non-respondents. We did not observe any significant differences between the two groups. We also compared firms that responded to the survey with the set of firms founded before 1990 and were pulled into bankruptcy court between January 1, 1993 and January 1, 19975. The comparison showed that the firms in the survey are almost twice the size as the firms that suffered bankruptcy by January 1 ,

\footnotetext{
${ }^{4}$ From 1940 to 1991,30 countries recognized Lithuania as an independent, though annexed, country.

${ }^{5}$ There were no bankruptcies filed in Lithuania prior to January 1, 1993.
} 
1997. This indicates that in general larger firms founded in the socialist system survived longer than smaller firms during that period.

Data Collection Process: A survey methodology was used since there is no archival data on firm level change in Central and Eastern Europe with regard to search for resources.

One difficulty with surveys in transitional and emerging economies is the concentration of information within enterprises (Hoskisson, Eden, Lau, and Wright, 2000). Therefore, we had to rely on a small set of individuals in each firm to provide us with the required data. This is consistent with prior survey research that relies on a single respondent (Zander and Kogut, 1995; May, Stewart, and Sweo, 2000; Capron, Dussauge, and Mitchell, 1998) or a set of respondents (Lyles and Baird, 1994). The survey examined the change process for six resources, each in a separate section. This allowed the appropriate specialist to complete each section. On average, 3.95 respondents participated in completing each survey. Respondent titles indicated that $80.3 \%$ of the respondents replied concerning resources within their primary area of specialty or responsibility. This selection of appropriate respondents is crucial in single respondent surveys (Capron, Dussauge, and Mitchell, 1998).

\footnotetext{
${ }^{8}$ Interviewees in Lithuania indicated that the term 'not applicable' for surveys has not been developed. The same interviews indicated that a zero with an explanation of 'not applicable' would be the best approach.
} 
Instrument: The survey examines six areas of operation or resources that companies in Lithuania needed to change to be effective in a free market system. These six areas were identified in prior research by Chikan and Demeter (1995) and Ericson (1998). The selection of these six areas was reconfirmed during our interviews with company management in June 2000. The six areas are: quality assurance systems, training programs, compensation and incentive systems, marketing programs, technology, and product or service line. These are the different resources of the firm, since resources include assets, processes and attributes controlled by the firm to implement strategies for better performance (Barney, 1991). In the survey instrument, a separate section was developed to collect relevant data for each resource or area; however, the questions within each section were the same.

An English version of the survey instrument was first prepared. This was then pre-tested with business students and business professors. One of the authors then translated the survey into Lithuanian. Following the principle of two-way translation for surveys (Hitt, Dacin, Levitas, Arregle, and Borza, 2000), this was further tested by two bi-lingual researchers for translation accuracy. We then tested the Lithuanian survey with 10 Lithuanian companies first in June 2000 and then pre-tested a revised survey in October 2000. The quality and completeness of the responses indicated that the survey was sufficient for use with a broader sample of firms.

\section{Measures}

Dependent Variables: This study uses two dependent variables: the location of search for resources $(\mathrm{H} 1)$ and the success of the resource change $(\mathrm{H} 2, \mathrm{H} 3, \mathrm{H} 4)$.

Location of Search: The dependent variable is dichotomous where $1=$ search for knowledge is distant (outside the former Soviet Union) and $0=$ search for knowledge is local (within the former Soviet Union). We selected this boundary of local vs. distant search to reflect the socialist economic system structure. The centralized feature of the planned economies resulted in high homogeneity between firms in a country with regard 
to their knowledge, so search throughout the country is similar to searching within the firm. In the survey, the respondent was asked if a contract was signed with a foreign firm for assistance to undertake the change as well as the country of origin of the firm. Signing of a contract was used to delineate major from minor assistance, since interviews indicated that firms do not obtain outside assistance without a contract. A contract was deemed as a clear, measurable event that would filter out minor assistance such as phone calls to colleagues. This variable is also used as an independent variable to test Hypothesis 2 and 4 . Table 1 indicates the number of firms that undertook a resource change within each resource, as well as the breakdown for local and distant search.

Success of the Change: For each of the six resources of interest, appropriate respondents in each firm were asked to evaluate each of 16 different reasons for the resource change (such as 'to increase sales' or 'to meet union demands') using a six-point scale. The list of reasons for resource change was the same in each of the six sections. This list was developed using prior research and fieldwork. During the pre-test with 10 firms, it was reviewed and finalized to its present form. Please see Appendix 1 for the full list of reasons for resource change and scale used. The respondents were asked to rate how successful the resource change was in fulfilling each of the 16 reasons. The scale was $1=$ not successful to $5=$ very successful, with $0=$ not applicable ${ }^{8}$. The sum of the ratings (from 0 to 5 ) for the 16 reasons for resource change is used as a measure of success of the resource change.

Independent Variables: This study uses two primary independent variables: the level of socialist imprinting for an area of activity (H1, H3, H4) and the location of search for knowledge (H2, H4). The location of search for resources is the same as defined under the dependent variables.

Level of Socialist Imprinting: In each of the six sections corresponding to the six resources, the respondent was asked to evaluate each of 16 different reasons for the resource change (such as 'to increase sales' or 'to meet union demands') using a six point scale. The list of reasons for resource change was the same in each of the six sections. 
The list of reasons for resource change is the same as used for the measure of success of the change, but we asked a different question. The respondents were asked to rate how important the reason was in deciding to undertake the resource change. The scale was 1 $=$ low importance to $5=$ high importance, with $0=$ not applicable ${ }^{9}$.

To develop the measure for socialist imprinting, the 16 reasons for change were split into three categories: socialist imprinting, no socialist imprinting, and neutral economic environment imprinting. We relied on prior research to classify the reasons for resource change into 'socialist imprinting' and 'no socialist imprinting'. The reasons reflecting socialist imprinting are those that were imprinted by the socialist system and are expected to continue to be reflective of socialist system principles. These include 'to satisfy domestic legal requirements', since during the initial stages of the transitional economy, many of the Soviet era laws remained on the books. They also include the reasons 'to meet labor union demands' and 'to meet employee demands', since attitudes and requirements continued to have a socialist legacy several years after the shock of the late 1980s and early 1990s (Blanchflower and Freeman, 1997). The six reasons defined as 'no socialist imprinting' are those that were not a factor during the socialist period, so no socialist imprinting could have occurred. They are: 'to meet customer requirements', since the customer was irrelevant in the socialist period (May, Stewart, and Sweo, 2000; Vlachoutsicos and Lawrence, 1996); 'to improve competitive position' and 'to build brand awareness' since competition was non-existent in the socialist system due to monopolistic conditions (May, Stewart, and Sweo, 2000; Pearce, 1991); 'to increase exports' and 'to increase sales', since in the socialist system, suppliers had a captive market (Filatotchev, Buck, and Zhukov, 2000; Carson, 1991; Pearce, 1991); and 'to improve quality' given the lack of competition and the focus on output (Granick, 1975). The reasons defined as having neutral economic imprinting are parameters whose importance and interpretation cannot be clearly linked to any specific imprinting.

The overall level for socialist imprinting on each resource was assessed by subtracting the average 'importance' score for the six 'no socialist imprinting' reasons from the average "importance" score for the socialist imprinting reasons. The importance

\footnotetext{
${ }^{9}$ The respondents were to evaluate the importance for each of the reasons as it stood prior to the resource

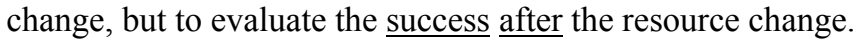


scores are used since it indicates the pressure from socialist or non-socialist reasons. The 'no socialist imprinting' score is subtracted, since those reasons for resource change act as counterbalancing reasons to the socialist based reasons. For example, if a firm undertakes a resource change solely to meet union demands, it is believed that socialist imprinting will be higher than if the reason to undertake resource change were balanced by the goals of 'to increase exports' and 'to improve competitive position'.

Control Variables: This study uses three control variables.

Size: Two measures for size, $\log$ of sales revenue in 1998 and $\log$ of the number of employees in 1998, were used. Size is expected to have a positive relationship with search location, as larger companies have more resources for distant search (which is more expensive) than will smaller companies. Only the results using revenues are provided, since using number of employees did not significantly change the results.

Industry: The firms are grouped into five industry categories: processing \& manufacturing (28), food processing (14), sales \& service (4), construction (10) and other such as utilities, chemicals, energy and transportation (11). This grouping is similar to that used by Khanna and Rivkin (2001). Dummy variables were assigned for each industrial category.

Exports: This study considers exports to the west as a percentage of revenue for 1998 . Export levels should reflect the level of ties with resource sources outside the country, so higher export levels should lead to higher probability of distant search. However, higher export levels may be indicative of other options to get resources from abroad than through a contracting mechanism. Since these two possibilities offset each other, the impact for exports cannot be determined.

\section{RESULTS AND ANALYSIS}

Correlations, means, and standard deviations for all variables are presented in Table 2 . Search location is negatively correlated with socialist imprinting and positively correlated with success, as suggested by Hypotheses 1 and 2. Socialist imprinting is also negatively correlated with success as predicted in Hypothesis 3. As is expected, the two values for size (employees and revenues) are highly correlated and the two measures for exports 
(overall and to the West) are also highly correlated. As a result only one control for size (revenues) and one control for exports (exports to West) are used. Hypothesis 1 considered the impact of socialist imprinting on the search location for knowledge. The results of the logit analysis testing this hypothesis are presented in Table 3.

We see that decreased levels of socialist imprinting are associated with distant search, but the coefficient value is not statistically significant. Thus, Hypothesis 1 is not fully supported. The control variables are also statistically insignificant. Table 4 provides the results of the OLS regression used to test Hypotheses 2, 3 and 4 which examine variables that influence resource change success.

Model 1 tests the relationship between search location and success and finds it strongly significant, providing support to Hypothesis 2. Distant search for knowledge is positively and significantly related to success of change. Model 2 tests the relationship between socialist imprinting and success. A negative relationship is observed as predicted but it is not statistically significant. In Model 3 we include both explanatory variables, search location and socialist imprinting, together in the analysis and the results are similar to those observed earlier. In Model 4 we add control variables in the analysis. As before, search location continues to be significant but among the controls only size is significantly related to success of change. This suggests that larger firms in general have higher levels of change success than smaller firms. Socialist imprinting continues to have a statistically insignificant relationship with the dependent variable. In Model 5 we introduce the interaction term to examine the joint effect of socialist imprinting and search location on success change. The interaction term is positively and significantly related to success providing support for Hypothesis 4. Model 6 is the full model with all the explanatory and control variables in the analysis; the results continue to remain the same as before.

\section{DISCUSSION}

In this paper we first sought to examine how founding conditions in terms of socialist imprinting influenced firm's location of search for knowledge to change their resources to adapt to the sudden exogenous shock in their external business environments. We had expected that firms with higher levels of socialist imprinting were 
more likely to engage in local search but our hypothesis was not fully supported. The lack of any significant relationship between socialist imprinting and search location perhaps reflects the effect of two opposing directions in which this relationship works. On the one hand, as we argued, firms with higher levels of socialist imprinting seek new knowledge locally given that such knowledge would be more similar to their existing resource base and therefore easier to combine. On the other hand, it may be that firms with higher levels of socialist imprinting actually seek new knowledge from more distant locations. This is because such knowledge would be more suitable to help change their resource base to meet the new economic environment of the post shock period more effectively. In the future, we need to investigate this relationship in greater depth.

We then sought to examine the independent and joint effects of socialist imprinting and search location on the success of resource change. As hypothesized in Hypothesis 2, we observed that distant search is associated with higher levels of resource change success. Our results suggest that, on average, firms that used distant rather than local search improved their average success level by almost 15\%. This result suggests that for firms that undergo a big change in their external business environment, knowledge required to work more effectively in that new environment is available in distant locations and sources. Knowledge from local sources that may still bear many traces of their earlier environment is much less useful in helping them change their resource base. As far as Hypothesis 3 was concerned, we failed to find significant support for it. On the other hand, we saw that socialist imprinting and search location had a significant joint impact on the success of change. Firms with higher levels of socialist imprinting that engaged in distant search as compared to local search exhibited greater levels of success. This supports the argument that for resources with higher levels of socialist imprinting instead of searching for locally available knowledge to combine with like knowledge or resources, firms are better off by acquiring knowledge from distant sources. Such distant knowledge, although dissimilar or different from the firm's existing knowledge or resource base, is more effective in eventually changing the resource base. Hopefully, it allows the firm to operate more successfully in the new environment.

The findings of this research may provide some useful insights to both managers and policy makers concerned with operating in transition economies. One, knowledge 
obtained from abroad can be used more effectively to change firms' resource base than normally believed. Two, there is need to evaluate how the strength of socialist imprinting interacts with the search location for new knowledge to undertake change. In some cases it may be useful to work with the current set of resources and seek knowledge from local sources inherited largely from the previous socialist system. In other cases, it may be worthwhile obtaining new resources and knowledge from distant sources that are better suited to the new and changed economic environment. From a policy maker's standpoint, it highlights the fact that some firms in transitional economies are not immobile but are able to change their resource base quite successfully. Policy makers should also realize that firms in such economies are able to use both local and distant search to identify the knowledge required for change but that the location of search, jointly with the level of socialist imprinting, impacts the eventual success of that change.

In the future, we can undertake several actions to address some of the shortcomings present in this study. One, we can develop new measures for some of the key variables in the study. For the success of resource change, it may be more preferable to use some quantitative measures of such change. However, most firms in many transitional economies have not yet developed consistent processes and measures to track such changes. A few that have done so are not comfortable sharing such information that they consider proprietary to their firms. Hopefully, in the future, we shall have a sufficient number for firms willing to share such data. As far as the socialist imprinting measure is concerned it is limited in that uses the motivation to change a resource as a measure of the level of imprinting. Although constraints and opportunities do influence how resources are changed, it would be preferable to have a measure that is closer to measuring the imprinting on a resource more directly. A related limitation is that the present measure does not actually measure the imprinting of the economic environment at the time of founding. Rather, it measures imprinting of resources in the immediate postshock period and assumes it is closely correlated with original imprinting in the socialist period. In the future, it would be useful to rectify both these shortcomings. It would be equally interesting to not only examine the resources of previously socialist firms and how they operate or change in the new market economy as we do in this study but also to compare them with firms founded in the market based economy prevalent after 1990. 
Such a contrast can potentially shed light on differences in socialist imprinting across the two groups and subsequently its link to resource change and how they undertake change.

\section{CONCLUSION}

In this paper we examine how firms change their resources in response to exogenous shocks in their business environment. Building on core ideas from the literatures on organizational imprinting and firm resources, we suggest that founding conditions differentially imprint firm resources. These initial imprinting differentials in turn influence their search for knowledge required to adapt or change firm resources in the face of external change in their business environment. We also suggest that the level of imprinting and the location of search independently and jointly influence the success with which firms are able to change their resources. We use survey-based data from a set of firms in Central Europe that experienced an exogenous shock in 1989-1991 to test our arguments. We develop a measure of pre-shock imprinting (called socialist imprinting) on resources and use it to predict where firms will search for knowledge to undertake change in the post-shock period and how successful that change will be. We find that the level of socialist imprinting influences the search location for knowledge to change key resources and activities following the shock. In terms of the success of change undertaken, we see that distant search for knowledge is positively linked to it. We also observe that the level of imprinting and search location jointly impact the success of change; for resources with higher socialist imprinting, distant search was more effective than local search. For policy makers and firm managers, it indicates that resources can be more easily changed using new knowledge than perhaps previously believed. The stereotype of socialist firms resisting change and having a lifetime liability from the socialist system needs to be reconsidered. 
TABLE 1: Frequency of Change and Search Location for New Resources for Areas of Activity

$\begin{array}{llccc} & \text { N } & \text { \# Changed } & \text { Local Search Distant Search } \\ \text { Quality Assurance } & 67 & 49 & 36 & 13 \\ \text { Training } & 67 & 61 & 48 & 13 \\ \text { Wage and Compensation } & 67 & 55 & 55 & 0 \\ \text { Marketing } & 67 & 53 & 48 & 5 \\ \text { Technology } & 67 & 63 & 49 & 14 \\ \text { Product and Service } & 67 & 57 & 44 & 13\end{array}$

TABLE 2: Correlation Matrix and Descriptive Statistics for Main Variables in the Regression Analysis

$\begin{array}{llllllllll} & \text { Mean } & \text { s.d. } & \mathbf{1} & \mathbf{2} & \mathbf{3} & \mathbf{4} & \mathbf{5} & \mathbf{6} & \mathbf{7} \\ \text { Search Location } & .17 & .37 & 1.00 & & & & & & \\ \text { Success } & 41.2 & 11.0 & .174^{* *} & 1.00 & & & & & \\ \text { Socialist Imprinting } & -5.0 & 3.0 & -.051 & -.027 & 1.00 & & & & \\ \text { Revenues (ln) } & 16.2 & 1.03 & .091 & .062 & -.038 & 1.00 & & & \\ \text { Employees (ln) } & 6.2 & .87 & .083 & .090 & -.013 & .644^{* *} & 1.00 & & \\ \text { Exports (\%) } & 31 & 33 & .063 & .189 * * & -.015 & .259^{* *} & .470^{* *} & 1.00 & \\ \text { Exports West (\%) } & 23 & 30 & .087 & .187^{* *} & -.025 & .271^{* *} & .432^{* *} & .862^{* *} & 1.00 \\ \text { N=338 } & & & & & & & & & \\ \text { ** Pearson Correlation is significant at the } 0.01 \text { level (2-tailed) } & & & & & \\ \text { * Pearson Correlation is significant at the } 0.05 \text { level (2-tailed) } & & & & & \end{array}$


Table 3: Logit Regression Analysis examining the relationship between Socialist Imprinting and Search Location

\begin{tabular}{|c|c|c|c|c|c|}
\hline & Model 1 & Model 2 & Model 3 & Model 4 & Model 5 \\
\hline Constant & $-1.8 * *$ & $-5.3 * *$ & $-4.7 *$ & $-6.3^{*}$ & $-6.0 *$ \\
\hline $\begin{array}{l}\text { Socialist } \\
\text { Imprinting }\end{array}$ & -.096 & -.090 & -.090 & -.112 & .137 \\
\hline Size & & .212 & .168 & .238 & .260 \\
\hline Exports & & & .566 & .635 & .577 \\
\hline Industry & & & & Not Sig & Not Sig \\
\hline Resource & & & & & Not Sig \\
\hline
\end{tabular}

** - indicates significance at $\mathrm{p}<0.01$

* - indicates significance at $\mathrm{p}<0.05$ 
William Davidson Institute Working Paper 446

Table 4: Regression Analysis highlighting factors influencing success of change.

\begin{tabular}{|c|c|c|c|c|c|c|}
\hline & Model 1 & Model 2 & Model 3 & Model 4 & Model 5 & Model 6 \\
\hline Constant & $41.2^{* *}$ & $40.7 * *$ & $40.0 * *$ & 13.1 & $40.6^{* *}$ & 14.6 \\
\hline Search Loc. & $5.10 * *$ & & $5.08 * *$ & $3.81 *$ & $5.67 * *$ & $4.36^{* *}$ \\
\hline $\begin{array}{l}\text { Socialist } \\
\text { Imprinting }\end{array}$ & & -.209 & -.142 & .335 & .115 & .400 \\
\hline $\begin{array}{l}\text { Imprinting * } \\
\text { Search Loc. }\end{array}$ & & & & & $4.15^{* *}$ & $2.85^{* *}$ \\
\hline Size & & & & $1.74 *$ & & $1.65^{*}$ \\
\hline Exports & & & & 4.33 & & 3.75 \\
\hline Industry & & & & Not Sig & & Not Sig \\
\hline Resource & & & & Not Sig & & Not Sig \\
\hline Adj. R-square & .027 & -.002 & .025 & .109 & .050 & .119 \\
\hline F-value & 10.44 & .254 & 5.27 & 4.181 & 5.29 & 4.26 \\
\hline
\end{tabular}

$(\mathrm{N}=338)$

** - indicates significance at $\mathrm{p}<0.01$

$*$ - indicates significance at $\mathrm{p}<0.05$ 


\section{BIBLIOGRAPHY}

Amit, Raphael; Schoemaker, Paul J.H. (1993). "Strategic Assets and Organizational Rent". Strategic Management Journal. Vol. 14, No. 1; pgs. 33-46.

Anand, Jaideep; Singh, Harbir (Summer Special Issue 1997). “Asset Redeployment, Acquisitions and Corporate Strategy in Declining Industries". Strategic Management Journal. Vol. 18; pgs. 99-118.

Bamford, Charles E.; Thomas J. Dean; Patricia P. McDougall. 1999. "An Examination Of The Impact of Initial Conditions And Decisions Upon The Performance of New Bank Start-Ups". Journal of Business Venturing. Vol. 15; pgs. 253-277.

Banbury, Catherine M. and Will Mitchell. 1995. "The Effect of Introducing Important Incremental Innovations On Market Share and Business Survival”. Strategic Management Journal. Vol. 16; pgs. 161-182.

Barker, Vincent L. III; Duhaime, Irene (1997). "Strategic Change in the Turnaround Process: Theory and Empirical Evidence". Strategic Management Journal. Vol. 18; pgs. 13-38.

Barnett, William P.; Carroll, Glenn R. (1985). "Modeling Internal Organizational Change”. Annual Review of Sociology. Vol. 21; pgs. 217-236.

Barney, Jay B. (1991). "Firm Resources and Sustained Competitive Advantage". Journal of Management. Vol. 17, No. 1; pgs. 99-120.

Blanchflower, David G.; Freeman, Richard B. April 1997. "The attitudinal legacy of communist labor relations." Industrial \& Labor Relations Review Vol. 50, No. 3, pgs. 438-459.

Boeker, Warren. 1989. "Strategic Change: The Effects of Founding and History". Academy of Management Journal. Vol. 22, No. 3; pgs. 489-515.

Capron, Laurence; Dussauge, Pierre; Mitchell, Will (1998). "Resource Redeployment Following Horizontal Acquisitions in Europe and North America (1988-1992)". Strategic Management Journal. Vol. 19; pgs. 631-661.

Capron, Laurence and Will Mitchell. Draft: May 14, 1999. "The Impact of Relevant Resources and Market Failure on Four Modes of Business Change: A Conceptual Framework with Examples from the Corporate Client Segment of the Information Communication Technology Business." Forthcoming.

Carroll, Glenn R. and Michael T. Hannan. 2000. The Demography of Corporations and Industries. Princeton University Press; Princeton, New Jersey.

Carson, Richard L. Fall 1991. "On the Decline of Socialism". Comparative Economic Studies. Vol. 33, No. 3; pgs. 167-177.

Chikan, Attila and Krisztina Demeter. 1995. "Manufacturing strategies in Hungarian industry: The effects of transition from planned to market economy." International Journal of Operations \& Production Management 15 11: 5-20. 
Cohen W. and D. Levinthal. 1990. "Absorptive capacity: A new perspective on learning and innovation”. Administrative Science Quarterly. Vol. 35; pgs. 128-152.

Cyert, Richard M. and James G. March. 1963. A behavioral theory of the firm. Englewood Cliffs, N.J.: Prentice-Hall.

Dial, Jay and Kevin J. Murphy. 1995. "Incentives, downsizing, and value creation at General Dynamics”. Journal of Financial Economics. Vol. 37; pgs. 261-314.

DiMaggio, Paul J.; Powell, Walter W. (1991). "Introduction to the New Institutionalism". The New Institutionalism in Organizational Analysis. (eds) Walter W. Powell and Paul DiMaggio; University of Chicago Press, Chicago; pgs. 1-38.

Eisenhardt, Kathleen M. and Claudia Bird Schoonhoven. 1990. "Organizational Growth: Linking Founding Team, Strategy, Environment, and Growth among U.S. Semiconductor Ventures, 19781988”. Administrative Science Quarterly. Vol. 35; pgs. 504-529.

Ericson, Richard E. Summer 1998. "Restructuring in transition: Conception and Measurement." Comparative Economic Studies 40:2 103-108.

Filatotchev, Igor; Buck, Trevor; Zhukov, Vladimir (2000). "Downsizing in Privatized Firms in Russia, Ukraine, and Belarus". Academy of Management Journal; Vol. 43, No. 3; pgs. 286-304.

Granick, David. 1975. Enterprise Guidance in Eastern Europe: A Comparison of Four Socialist Economies. Princeton University Press: Princeton, New Jersey.

Grant, Robert M. 1996. “Toward a Knowledge-Based Theory of the Firm”. Strategic Management Journal. Vol. 17, Winter Special Issue; pgs. 109-122.

Hanna, Michael T. and John Freeman. 1977. "The Population Ecology of Organizations" American Journal of Sociology. Vol. 82, No. 5; pgs. 929-964.

Hanna, Michael T. and John Freeman. 1984. "Structural Inertia and Organizational Change". American Sociological Review. Vol.49, No. 2; pgs. 149-164.

Henderson, Rebecca M. and Kim B. Clark. 1990. "Architectural Innovation: The Reconfiguration of Existing Product Technologies and the Failure of Established Firms". Administrative Science Quarterly. Vol. 35; pgs. 9-30.

Hitt, Michael; Dacin, Tina; Levitas, Ed; Arregle, Jean-Luc; Borza, Anca. (2000). "Partner Selection in Emerging and Developed Market Contexts: Resource-Based and Organizational Learning Perspectives". Academy of Management Journal. Vol. 43, No. 3; pgs. 449-467.

Hoskisson, Robert E.; Eden, Lorraine; Lau, Chung Ming; Wright, Mike (2000). "Strategy in Emerging Economies". Academy of Management Journal. Vol. 43, No. 3; pgs. 249-267.

Khanna, Tarun and Jan W. Rivkin, Jan W. 2001. "Estimating the Performance Effects of Business Groups in Emerging Markets". Strategic Management Journal. Vol. 22, pgs. 45-74. 
Kogut, Bruce. 1993. Learning, or the Importance of being Inert: Country Imprinting and International Competition from Organization Theory and the Multinational Corporation. Edited by Sumantra Ghoshal and D. Eleanor Westney. St. Martin's Press. New York; pgs. 136-154.

Leonard-Barton, Dorothy. 1992. "Core Capabilities and Core Rigidities: A Paradox in Managing New Product Development”. Strategic Management Journal. Vol. 13; pgs. 111-125.

Lyles, Marjorie A.; Baird, Inga S. (1994). "Performance of International Joint Ventures in Two Eastern European Countries: The Case of Hungary and Poland". Management International Review. Vol. 34, No. 4; pgs. 313-329.

May, Ruth C.; Wayne H. Stewart Jr. and Robert Sweo. 2000. Environmental Scanning Behavior in a Transitional Economy: Evidence from Russia. Academy of Management Journal. Vol. 43, No. 2; pgs. 403-427.

Mintzberg, Henry and James A. Waters. 1982. "Tracking Strategy in an Entrepreneurial Firm". Academy of Management Journal. Vol. 25, No. 3; pgs. 465-499.

Nagarajan, Anuradha and Will Mitchell. 1998. "Evolutionary diffusion: Internal and external methods used to acquire encompassing, complementary, and incremental technological changes in the lithotripsy industry". Strategic Management Journal. Vol. 19, Issue 11; pgs. 1063-1077.

Nelson, Richard R., and Sidney Winter. 1982. An Evolutionary Theory of Economic Change. Cambridge: Harvard University Press.

Pearce, Jone L. (1991). "From Socialism to Capitalism: the Effects of Hungarian Human Resources Practices”. Academy of Management Executive. Vol. 5, No. 4; pgs. 75-88.

Pennings, Johannes M. 1982. "Organizational Birth Frequencies: An Empirical Investigation". Administrative Science Quarterly. Vol. 27; pgs. 120-144.

Penrose, Edith G. (1959). The Theory of the Growth of the Firm. New York, Wiley.

Raymond, Louis; Pierre-Andre Julien, and Charles Ramangapahy. 2001. "Technological Scanning by Small Canadian Manufacturers". "Journal of Small Business Management". Vol. 39, No. 2; pgs. 123-138.

Romanelli, Elaine. 1989. "Environments and Strategies of Organization Start-up: Effects on Early Survival”. Administrative Science Quarterly. Vol. 34; pgs. 369-387.

Rubin, Paul H. (1973). “The Expansion of Firms”. Journal of Political Economy; pgs. 936-949.

Sastry, Anjali and Corinne Coen. July 2000. "Beyond the beginning: Building a theory of organizational imprinting". Working Paper - University of Michigan.

Schein, Edgar H. Summer 1983. "The Role of the Founder in Creating Organizational Culture". Organizational Dynamics.

Staw, Barry M.; Lance E. Sandelands and Jane E. Dutton. Dec 1981. "Threat-Rigidity Effects in Organizational Behavior: A Multilevel Analysis." Administrative Science Quarterly 26:4 501524. 
Stinchcombe, Arthur L. 1965. Social Structure and Organizations from Handbook of Organizations. Edited by James G. March. Rand McNally \& Company. Chicago; pgs. 142-193.

Stuart, Toby E and Joel M Podolny. Summer 1996. "Local search and the evolution of technological capabilities." Strategic Management Journal 17:21-39.

Szulanski, Gabriel. 1996. "Exploring Internal Stickiness: Impediments to the Transfer of Best Practice Within the Firm". Strategic Management Journal. Vol. 17; pgs. 27-43.

Teece, David J.; Pisano, Gary; Shuen, Amy (1997). "Dynamic Capabilities and Strategic Management”. Strategic Management Journal. Vol. 18, No. 7; pgs. 509-533.

Tucker, David J.; Jitendra V. Singh; Agnes G. Meinhard. 1990. "Organizational Form, Population Dynamics, and Institutional Change: The Founding Patterns of Voluntary Organizations". Academy of Management Journal. Vol. 33, No. 1; pgs. 151-178.

Vlachoutsicos, Charalambos A.; Paul R. Lawrence. 1996. "How Managerial Learning Can Assist Economic Transformation in Russia". Organization Studies. Vol. 17, No. 2; pgs. 311-325.

Wernerfelt, Birger (1984). “A Resource-Based View of the Firm”. Strategic Management Journal. Vol. 5; pgs. 171-180.

Wernerfelt, Birger (1995). “The Resource-Based View of the Firm: Ten Years After”. Strategic Management Journal. Vol. 16; pgs. 171-174.

Zander, Udo; Kogut, Bruce (January-February 1995). "Knowledge and the Speed of the Transfer and Imitation of Organizational Capabilities: An Empirical Test”. Organization Science Vol. 6, No. 1; pgs. 76-92.

Zyglidopoulos, Stelios. March 1999. "Initial Environmental Conditions and Technological Change”. Journal of Management Studies. Vol. 36, No. 2; pgs. 241-262. 


\section{APPENDIX 1}

REASON FOR RESOURCE CHANGE

SUCCESS

$\begin{array}{lllllll} & \text { N/A } & \text { Low } & & & & \text { Hi } \\ \text { to reduce costs } & 0 & 1 & 2 & 3 & 4 & 5 \\ \text { to increase exports } & 0 & 1 & 2 & 3 & 4 & 5 \\ \text { to satisfy customer requirements } & 0 & 1 & 2 & 3 & 4 & 5 \\ \text { to improve product quality } & 0 & 1 & 2 & 3 & 4 & 5 \\ \text { to track costs better } & 0 & 1 & 2 & 3 & 4 & 5 \\ \text { to satisfy domestic investor requirements } & 0 & 1 & 2 & 3 & 4 & 5 \\ \text { to satisfy foreign investor requirements } & 0 & 1 & 2 & 3 & 4 & 5 \\ \text { to satisfy domestic legal requirements } & 0 & 1 & 2 & 3 & 4 & 5 \\ \text { to improve competitive position } & 0 & 1 & 2 & 3 & 4 & 5 \\ \text { to meet union demands } & 0 & 1 & 2 & 3 & 4 & 5 \\ \text { to meet employee demands } & 0 & 1 & 2 & 3 & 4 & 5 \\ \text { to increase sales } & 0 & 1 & 2 & 3 & 4 & 5 \\ \text { to build brand awareness } & 0 & 1 & 2 & 3 & 4 & 5 \\ \text { to reflect change in management structure } & 0 & 1 & 2 & 3 & 4 & 5 \\ \text { to improve employee skills } & 0 & 1 & 2 & 3 & 4 & 5 \\ \text { to improve productivity } & 0 & 1 & 2 & 3 & 4 & 5\end{array}$

\section{APPENDIX 2: 'SOCIALIST IMPRINTING' MEASURE}

Socialist Impact

to satisfy domestic legal requirements

to meet union demands

to meet employee demands

No Socialist Impact

to satisfy customer requirements

to build brand awareness

to improve competitive position

to increase exports

to improve product quality

to increase sales

Neutral Impact

to reflect change in management structure

to improve employee skills

to reduce costs

to improve productivity (output/input)

to track costs better

to satisfy foreign investor requirements

to satisfy domestic investor requirements 


\section{DAVIDSON INSTITUTE WORKING PAPER SERIES - Most Recent Papers}

The entire Working Paper Series may be downloaded free of charge at: www.wdi.bus.umich.edu

CURRENT AS OF 3/7/02

\begin{tabular}{|c|c|c|}
\hline Publication & Authors & Date \\
\hline $\begin{array}{l}\text { No. 446: The Impact of Socialist Imprinting and Search for Knowledge } \\
\text { on Resource Change: An Empirical Study of Firms in Lithuania }\end{array}$ & $\begin{array}{l}\text { Aldas Kriauciunas and Prashant } \\
\text { Kale }\end{array}$ & Mar. 2002 \\
\hline $\begin{array}{l}\text { No. 445: The Costs, Wealth Effects, and Determinants of International } \\
\text { Capital Raising: Evidence from Public Yankee Bonds }\end{array}$ & $\begin{array}{l}\text { Darius P. Miller and John J. } \\
\text { Puthenpurackal }\end{array}$ & Oct. 2001 \\
\hline No. 444: Financial Institutions, Contagious Risks, and Financial Crises & $\begin{array}{l}\text { Haizhou Huang and Chenggang } \\
\mathrm{Xu}\end{array}$ & Nov. 2001 \\
\hline No. 443: Banks as Catalysts for Industrialization & $\begin{array}{l}\text { Marco Da Rin and Thomas } \\
\text { Hellman }\end{array}$ & Oct. 2001 \\
\hline $\begin{array}{l}\text { No. 442: Bank-Based or Market-Based Financial Systems: Which is } \\
\text { Better? }\end{array}$ & Ross Levine & Feb. 2002 \\
\hline $\begin{array}{l}\text { No. 441: Migration and Regional Adjustment and Asymmetric Shocks } \\
\text { in Transition Economies }\end{array}$ & Jan Fidrmuc & Feb. 2002 \\
\hline $\begin{array}{l}\text { No. 440: Employment and Wages in Enterprises Under Communism } \\
\text { and in Transition: Evidence From Central Europe and Russia }\end{array}$ & $\begin{array}{l}\text { Swati Basu, Saul Estrin, and Jan } \\
\text { Svejnar }\end{array}$ & June 2000 \\
\hline No. 439: Small business in Russia: A Case Study of St. Petersburg & Alessandro Kihlgren & Jan. 2002 \\
\hline $\begin{array}{l}\text { No. 438: Foreign Direct Investment as Technology Transferred: } \\
\text { Some Panel Evidence from the Transition Economies }\end{array}$ & $\begin{array}{l}\text { Nauro F. Campos and Yuko } \\
\text { Kinoshita }\end{array}$ & Jan. 2002 \\
\hline No. 437: Whistleblowing, MNC's and Peace & Terry Morehead Dworkin & Feb. 2002 \\
\hline $\begin{array}{l}\text { No. 436: A Note on Measuring the Unofficial Economy in the Former } \\
\text { Soviet Republics }\end{array}$ & $\begin{array}{l}\text { Michael Alexeev and William } \\
\text { Pyle }\end{array}$ & Sept. 2001 \\
\hline $\begin{array}{l}\text { No. 435: The Ownership School vs. the Management School of State } \\
\text { Enterprise Reform: Evidence from China }\end{array}$ & David D. Li and Changqi Wu & Jan. 2002 \\
\hline $\begin{array}{l}\text { No. 434: The Effect of Ownership and Competitive Pressure on Firm } \\
\text { Performance in Transition Countries: Micro Evidence from Bulgaria, } \\
\text { Romania and Poland. }\end{array}$ & $\begin{array}{l}\text { Manuela Angelucci, Saul Estrin, } \\
\text { Jozef Konings, Zbigniew } \\
\text { Zolkiewski }\end{array}$ & Jan. 2002 \\
\hline No. 433: The End of Moderate Inflation in Three Transition Economies? & Josef C. Brada and Ali M. Kutan & Jan. 2002 \\
\hline $\begin{array}{l}\text { No. 432: What Drives the Speed of Job Reallocation During Episodes of } \\
\text { Massive Adjustment? }\end{array}$ & $\begin{array}{l}\text { Stepan Jurajda and Katherine } \\
\text { Terrell }\end{array}$ & Jan. 2002 \\
\hline $\begin{array}{l}\text { No. } 431 \text { Forthcoming in: The Journal of Economic Perspectives, } \\
\text { "Competition and Corporate Governance in Transition," 16(2) Feb. } \\
2002 \text {. }\end{array}$ & Saul Estrin & Dec. 2001 \\
\hline $\begin{array}{l}\text { No. 430: Corporate Governance in the Cause of Peace: An } \\
\text { Environmental Perspective }\end{array}$ & Don Mayer & Jan. 2002 \\
\hline No. 429: Why do Governments Privatize? & $\begin{array}{l}\text { Loren Brandt, Hongbin Li, and } \\
\text { Joanne Roberts }\end{array}$ & Dec. 2001 \\
\hline No. 428: Testing Russia's Virtual Economy & Vlad Ivanenko & Dec. 2001 \\
\hline No. 427: War and the Business Corporation & Eric W. Orts & Dec. 2001 \\
\hline $\begin{array}{l}\text { No. 426: Partial Privatization and Firm Performance: Evidence from } \\
\text { India }\end{array}$ & Nandini Gupta & Dec. 2001 \\
\hline $\begin{array}{l}\text { No. 425: Direct Foreign Investments and Productivity Growth in } \\
\text { Hungarian Firms, 1992-1999 }\end{array}$ & Jérôme Sgard & Nov. 2001 \\
\hline $\begin{array}{l}\text { No. 424: Banking Passivity and Regulatory Failure in Emerging } \\
\text { Markets: Theory and Evidence from the Czech republic. }\end{array}$ & Jan Hanousek and Gerard Roland & July 2001 \\
\hline $\begin{array}{l}\text { No. 423: Conceptions of the Corporation and the Prospects of } \\
\text { Sustainable Peace }\end{array}$ & Jeffrey Nesteruk & Dec. 2001 \\
\hline No. 422: The Role of the Corporation in Fostering Sustainable Peace & Timothy Fort and Cindy Schipani & Nov. 2001 \\
\hline No. 421: Wage Arrears and the Distribution of Earnings in Russia & $\begin{array}{l}\text { Hartmut Lehmann and Jonathan } \\
\text { Wadsworth }\end{array}$ & Dec. 2001 \\
\hline
\end{tabular}

